\title{
Homicide Cases During COVID-19 Pandemic at Prof. Dr. R. D. Kandou Hospital, Manado, in the Period between March 2020 and February 2021 \\ Kejadian Kasus Pembunuhan Saat Pandemi COVID-19 di RSUP Prof. Dr. R. D. Kandou Manado Periode Maret 2020 - Februari 2021
}

\author{
Jennifer T. Suwontopo, ${ }^{1}$ Nola T. S. Mallo, ${ }^{2}$ Erwin G. Kristanto ${ }^{2}$ \\ ${ }^{1}$ Program Studi Pendidikan Dokter Fakultas Kedokteran Universitas Sam Ratulangi, Manado, \\ Indonesia \\ ${ }^{2}$ Bagian Ilmu Kedokteran Forensik Fakultas Kedokteran Universitas Sam Ratulangi, Manado, \\ Indonesia \\ Email: jennifersuwontopo@gmail.com \\ Received: December 25, 2021; Accepted: February 9, 2022; Published on line: February 13, 2022
}

\begin{abstract}
There are various cases of problems in the legal field; one of which is homicide. This study aimed to find out whether there was a difference in the number of homicides before the COVID-19 pandemic compared to during the COVID-19 pandemic at Prof. Dr. R. D. Kandou Hospital, Manado. This was a retrospective and descriptive study by reviewing the Visum et Repertum (VeR) data recorded at the Forensic Section of Prof. Dr. R. D. Kandou, Manado. Variables were type of violence, sex of victim, age group of victim, cause of death, and date of examination. The results showed that the number of homicides were 17 cases in the $2018-2019$ period and seven cases during the COVID-19 pandemic from March 2020 to February 2021 at Prof Dr. R. D Kandou, Manado, which indicated a decrease of 41\%. Male was the dominant sex of victims. Group of teenagers aged 17-25 years, early adulthood 26-35 years old, and late adult group 36-45 years old had the same number of cases; each of two cases. The most common cause of death was sharp violence. In conclusion, there is a decrease of homicide cases during the COVID-19 pandemic. Most cases were male with sharp violence as the cause of death.
\end{abstract}

Keywords: homicide case; COVID-19

\begin{abstract}
Abstrak: Terdapat berbagai macam kasus permasalahan yang terjadi di dalam bidang hukum, salah satunya yaitu kasus pembunuhan. Penelitian ini bertujuan untuk mengetahui apakah terdapat perbedaan jumlah kasus pembunuhan sebelum pandemi COVID-19 dibandingkan pada era pandemi COVID-19 di RSUP Prof. Dr. R. D. Kandou Manado. Jenis penelitian ialah deskriptif retrospektif dengan melakukan peninjauan data Visum et Repertum (VeR) yang tercatat di Bagian Forensik RSUP Prof. Dr. R. D. Kandou Manado. Variabel penelitian yang digunakan yaitu: jenis kekerasan, jenis kelamin korban, kelompok usia korban, sebab kematian, tanggal pemeriksaan. Hasil penelitian mendapatkan angka kasus pembunuhan pada era pandemi COVID-19 periode Maret 2020-Februari 2021 di RSUP Prof Dr. R. D. Kandou Manado mengalami penurunan sebesar 41\%, yaitu dari 17 kasus pada periode 2018-2019 menjadi tujuh kasus selama pandemi COVID-19 pada periode Maret 2020-Februari 2021 yang dilakukan autopsi; terbanyak didapatkan pada bulan Juli 2020, dengan jenis kelamin korban yang terbanyak yaitu laki-laki. Berdasarkan usia, kelompok usia remaja berusia 17-25 tahun, kelompok dewasa awal 26-35 tahun, kelompok dewasa akhir berusia 36-45 tahun, masing-masing berjumlah dua kasus dengan sebab kematian berupa kekerasan tajam. Simpulan penelitian ini ialah terdapat penurunan jumlah kasus pembunuhan pada era pandemi COVID-19 dibandingkan sebelum pandemi. Korban terbanyak berjenis kelamin laki-laki, dengan sebab kematian berupa kekerasan tajam
\end{abstract}

Kata kunci: kasus pembunuhan; COVID-19 


\section{PENDAHULUAN}

Ilmu Kedokteran Forensik merupakan salah satu cabang ilmu kedokteran yang digunakan untuk membantu memecahkan berbagai macam permasalahan dalam bidang hukum. Ilmu Kedokteran Forensik menggunakan bukti sebagai pedoman untuk memecahkan terjadinya suatu permasalahan. ${ }^{1}$ Terdapat berbagai macam kasus permasalahan yang terjadi di dalam bidang hukum, salah satunya yaitu kasus pembunuhan. Apabila seseorang mempunyai rencana untuk melukai ataupun mengakhiri kehidupan dari seseorang atau sekelompok orang dan melakukannya maka kejadian tersebut bisa dikatakan sebagai kasus pembunuhan. ${ }^{2}$

World Health Organization (WHO) mencatat setidaknya 450.000 kasus pembunuhan yang terjadi di seluruh dunia pada tahun 2012 (6,7/100.000 populasi) dengan $60 \%$ korban ialah laki-laki dan rentang usia 15-44 tahun. ${ }^{2}$ Hasil penelitian yang didapatkan pada tahun 2018-2019 di Kota Manado berjumlah 17 kasus dimana pelaku terbanyak berjenis kelamin laki-laki yang berusia antara 17-25 tahun. ${ }^{3}$

COVID-19 bermula dari negara Cina pada Bulan Desember 2019. Pada tanggal 11 Maret 2020, WHO menyatakan COVID19 sebagai pandemi global. ${ }^{4}$ COVID-19 awalnya mengakibatkan kerugian besar bagi negara Cina dari bulan Desember 2019 Februari 2020. Namun, pada tanggal 2 Maret 2020 Presiden Joko Widodo mengonfirmasi dua kasus positif COVID-19 di Indonesia. ${ }^{5}$ Akibat dari pandemi COVID-19 maka pada tanggal 31 Maret 2020 Presiden Joko Widodo menandatangani peraturan pemerintah mengenai pemberlakuan Pembatasan Sosial Berskala Besar (PSBB) dan pada 13 Januari 2021 program vaksinasi massal seluruh Indonesia dimulai yang dibuka dengan pemberian vaksin pertama kepada presiden Joko Widodo. ${ }^{5}$

\section{METODE PENELITIAN}

Penelitian ini merupakan penelitian deskriptif retrospektif dengan melakukan peninjauan data Visum et Repertum (VeR) yang tercatat di Bagian Forensik RSUP Prof Dr. R. D. Kandou Manado. Populasi sampel yang diambil yaitu semua kasus baik anak maupun dewasa yang tercatat di berkas data RSUP Prof. Dr. R. D. Kandou Manado. Variabel penelitian yang digunakan pada penelitian yaitu jenis kekerasan, jenis kelamin korban, kelompok usia korban, sebab kematian, dan tanggal pemeriksaan.

Penelitian ini telah mendapat persetujuan dari Komisi Etik Penelitian Kesehatan RSUP Prof. Dr. R. D. Kandou Manado dengan nomor surat keterangan layak etik No. 200/EC/KEPK-KANDOU/XI/2021.

\section{HASIL PENELITIAN}

Berdasarkan hasil penelitian deskriptif retrospektif yang telah dilakukan di Bagian Forensik RSUP Prof Dr. R. D. Kandou Manado periode Maret 2020-Februari 2021 tercatat sebanyak tujuh kasus, yang terdiri dari enam kasus pada tahun 2020 dan hanya satu kasus pada tahun 2021 yang terlapor.

Gambar 1 memperlihatkan bahwa selama masa periode pandemi hanya terdapat tujuh kasus pembunuhan. Dari ketujuh kasus tersebut sebanyak dua kasus (28\%) terjadi pada kelompok usia remaja (17-25 tahun), dua kasus (28\%) terjadi pada kelompok usia dewasa awal (26-35 tahun), dua kasus $(28 \%)$ terjadi pada kelompok usia dewasa akhir, dan hanya satu (16\%) kasus yang terjadi pada kelompok usia lansia akhir (56-65 tahun). Hal ini menunjukkan bahwa kejadian pembunuhan lebih sering menimpa kelompok remaja dan dewasa dibandingkan kelompok lansia.

Gambar 2 memperlihatkan bahwa dari ketujuh kasus yang terlapor hanya sebanyak dua kasus (28\%) yang terjadi pada kelompok berjenis kelamin perempuan, dan sebanyak lima kasus $(72 \%)$ yang terjadi pada kelompok berjenis kelamin laki-laki. Hal ini menunjukkan bahwa kejadian pembunuhan lebih sering terjadi pada kelompok berjenis kelamin laki-laki dibandingkan kelompok berjenis kelamin perempuan.

Gambar 3 memperlihatkan bahwa dari ketujuh kasus terlapor sebanyak lima kasus (71\%) terjadi pada bulan Juli 2020-Oktober 2020, dan hanya sebanyak dua kasus (29\%) yang terjadi pada bulan November 2020Februari 2021. Hal ini menunjukkan bahwa 
kejadian pembunuhan pada masa pandemi ini lebih banyak terjadi pada bulan Juli 2020-Oktober 2020 dibandingkan dengan kejadian pembunuhan yang terjadi pada bulan Maret 2020-Juni 2020 dan bulan November 2020-Februari 2021.

Gambar 4 memperlihatkan bahwa dari ketujuh kasus terlapor terdapat sebanyak empat kasus (57\%) terjadi karena kekerasan tajam, dan hanya sebanyak tiga kasus (43\%) terjadi karena kekerasan tumpul. Hal ini menunjukkan kejadian kasus pembunuhan lebih sering terjadi karena kekerasan tajam dibandingkan kekerasan tumpul.

Tabel 1 memperlihatkan bahwa pada ketujuh kasus tersebut didapatkan sebab kematian sebanyak lima kasus terjadi pada bagian muka tubuh korban, dan hanya sebanyak dua kasus yang terjadi pada bagian belakang tubuh korban. Berdasarkan

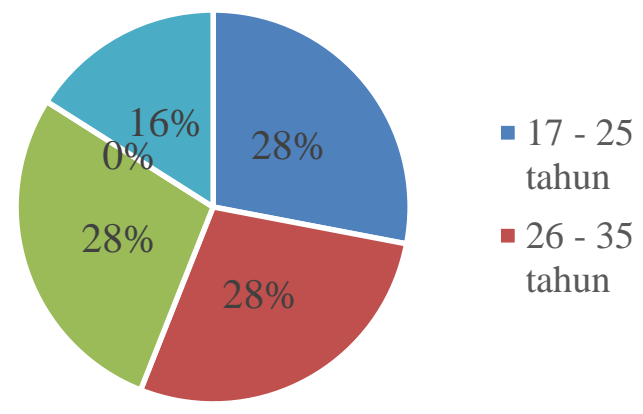

Gambar 1. Jumlah kasus pembunuhan di Kota Manado, Maret 2020 - Februari 2021 menurut usia korban
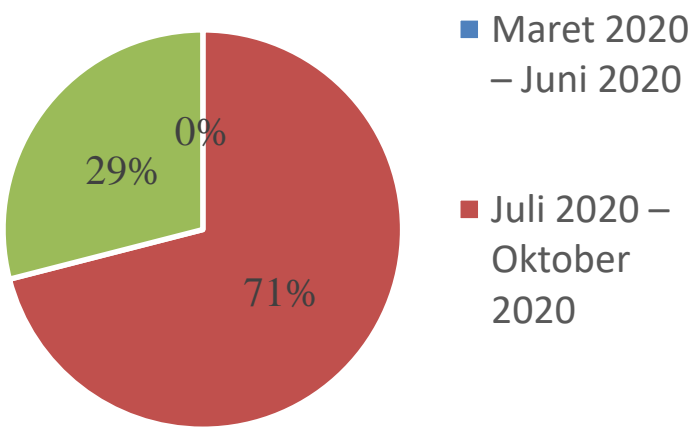

Gambar 3. Jumlah kasus pembunuhan di Kota Manado, Maret 2020 - Februari 2021 menurut tanggal pemeriksaan autopsi korban pola kekerasan dan lokasi kekerasan terdapat empat kasus dengan pola kekerasan tajam berupa luka tusuk di daerah dada dan leher serta tiga kasus dengan pola kekerasan tumpul berupa pukulan atau hantaman ke daerah kepala korban.

\section{BAHASAN}

Penelitian oleh Langelo et $\mathrm{al}^{3}$ yang menggunakan data laporan kasus pembunuhan dari Polresta Kota Manado Sulawesi Utara mendapatkan angka kasus pembunuhan pada tahun 2018-2019 sebanyak 17 kasus sedangkan hasil penelitian ini menggunakan data periode Maret 2020-Februari 2021 dan mendapatkan tujuh kasus. Hal ini menunjukkan bahwa terjadi penurunan kasus pembunuhan selama pandemi COVID-19 di RSUP Prof. Dr. R. D. Kandou Manado sebesar 41\% dibandingkan dengan dua tahun sebelumnya.

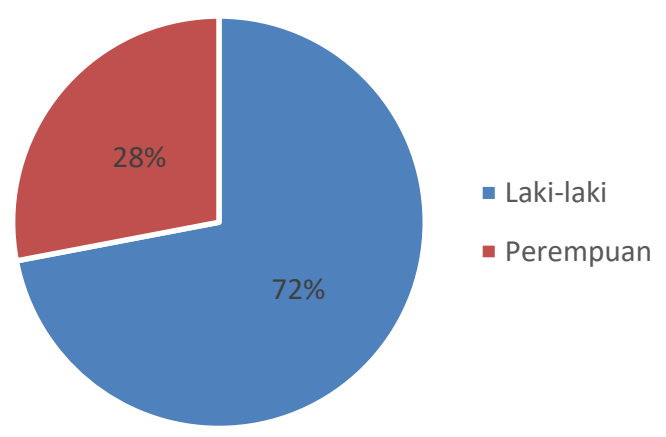

Gambar 2. Jumlah kasus pembunuhan di Kota Manado, Maret 2020 - Februari 2021 menurut jenis kelamin korban

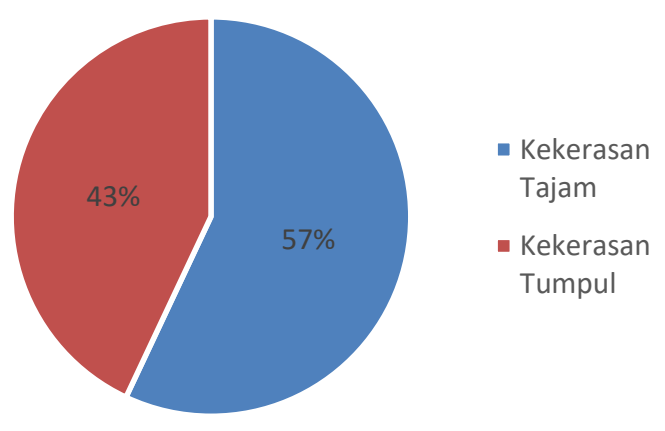

Gambar 4. Jumlah kasus pembunuhan di Kota Manado, Maret 2020 - Februari 2021 menurut jenis kekerasan 
Tabel 1. Jumlah kasus pembunuhan di Kota Manado, Maret 2020 - Februari 2021 menurut sebab kematian

\begin{tabular}{cl}
\hline No & \multicolumn{1}{c}{ Sebab Kematian } \\
\hline 1 & $\begin{array}{l}\text { Kekerasan tumpul pada daerah kepala belakang samping kanan yang menyebabkan } \\
\text { perdarahan dan kerusakan otak }\end{array}$ \\
2 & $\begin{array}{l}\text { Kekerasan tajam pada dada kanan yang menyebabkan putusnya pembuluh balik dan } \\
\text { pembuluh nadi dibawah tulang selangka kanan }\end{array}$ \\
3 & $\begin{array}{l}\text { Luka tusuk pada dada kiri menembus jantung } \\
4\end{array}$ \\
& $\begin{array}{l}\text { Kekerasan tumpul pada kepala korban yang menyebabkan kerusakan jaringan otak } \\
\text { yang besar }\end{array}$ \\
5 & Luka tusuk pada leher kiri yang memutus pembuluh darah nadi luar dan dalam \\
6 & $\begin{array}{l}\text { Luka tusuk pada dada kiri menembus pembuluh darah balik besar dari jantung ke } \\
\text { paru }\end{array}$ \\
7 & Kekerasan tumpul pada kepala yang mengakibatkan perdarahan dan memar otak \\
\hline
\end{tabular}

Setelah dilakukan pengambilan sampel, hanya tujuh sampel yang memenuhi kriteria inklusi yaitu sebanyak empat orang merupakan korban pembunuhan dengan kekerasan tajam dan sebanyak tiga orang merupakan korban pembunuhan dengan kekerasan tumpul. Sampel yang digunakan diambil dari berkas data di Bagian Forensik RSUP Prof. Dr. R. D. Kandou Manado periode Maret 2020-Februari 2021 setelah mendapatkan persetujuan layak etik dari Komite Etik RSUP Prof. Dr. R. D. Kandou Manado.

Lopez dan Rosenfeld ${ }^{6}$ meneliti tren berbagai kasus kriminal di Amerika Serikat sebelum pandemi dan saat pandemi COVID-19 dan mendapatkan bahwa selama periode pre pandemi untuk kasus pembunuhan sendiri, angka kejadian pembunuhan per 100.000 penduduk hanya sebesar $0,2-0,4$ kasus. Namun setelah pemberlakuan lockdown di Amerika Serikat pada bulan Maret 2020 laporan kasus pembunuhan mulai meningkat secara perlahan namun konsisten hingga mencapai puncaknya pada bulan Juli-Agustus 2020. Uniknya, jumlah kasus terus mengalami penurunan setelah kedua bulan tersebut hingga akhir tahun. Menurut kedua peneliti tersebut untuk tren kasus pembunuhan ini terdapat satu faktor yang patut dipertimbangkan sebelum menerima hasil yang diperoleh. Mereka mengemukakan bahwa faktor tersebut ialah adanya sebuah kasus pembunuhan yang dilakukan oleh polisi terhadap seorang bernama George Floyd pada bulan Mei di Kota
Minneapolis. Kasus ini menjadi trending topic selama beberapa bulan tidak hanya di Amerika saja bahkan di dunia. Bahkan kasus ini menjadi titik tolak demonstrasi masif di Amerika Serikat perihal kekerasan oleh polisi terhadap kaum minoritas. Kedua peneliti yaitu Lopes dan Rosenfeld menduga bahwa terdapat hubungan erat antara dampak sosial dari kasus pembunuhan tersebut dengan kenaikan jumlah kasus pembunuhan yang diamati. ${ }^{6-8}$ Walaupun belum dapat dibuktikan secara ilmiah namun mereka mencurigai hal tersebut karena adanya kejadian serupa di dalam sejarah Amerika Serikat yaitu pada tahun 2014 dilaporkan fenomena serupa yang dapat diamati setelah terjadi beberapa kasus pembunuhan oleh pihak kepolisian di berbagai kota seperti Ferguson, Missouri, dan Chicago. 6,9

Hasil penelitian ini mendapatkan bahwa korban terbanyak berada pada kelompok usia antara 17-25 tahun, 26-35 tahun, dan 36-45 tahun dengan jumlah kasus masingmasing sebanyak dua kasus (28\%), sedangkan untuk kelompok usia 56-65 tahun hanya terdapat satu kasus (16\%). Temuan ini sejalan dengan hasil penelitian yang dilakukan oleh Langelo et $\mathrm{al}^{3}$ yang mengambil periode tahun 2018-2019. Langelo et $\mathrm{al}^{3}$ mendapatkan dari total 17 kasus pembunuhan korban paling banyak berada pada kategori usia remaja hingga dewasa muda (17-25 tahun) dengan jumlah sebanyak 10 kasus $(59 \%)$. Untuk perbandingan kasus dalam periode yang serupa penulis memu- 
tuskan untuk melihat laporan dari Konsil Kepolisian Inggris dimana dilaporkan bahwa dari tanggal 1 April 2020 hingga 31 Maret 2021 total kasus kematian tidak wajar di negara tersebut berjumlah 215 kasus. Uniknya dari 215 kasus tersebut pembunuhan terutama pembunuhan pasangan intim (intimate partner homicide) memiliki jumlah tertinggi dengan total $49 \%$ kasus diikuti dengan pembunuhan anggota keluarga sebanyak $18 \%$ kasus. Diamati juga bahwa untuk tren korban didapatkan korban terbanyak berada pada kelompok usia 25-54 tahun yang menandakan tren serupa dimana lebih banyak korban berada pada masa remaja atau dewasa muda. ${ }^{10}$ Hal ini diduga dikarenakan oleh karena ketegangan atau masalah lainnya yang diperparah dengan isolasi akibat pandemi COVID-19. Ketegangan dalam suatu hubungan biasanya akan lebih mudah untuk memuncak terlebih pada masa lockdown dimana masyarakat saling berdiam di rumah dan tidak ada sarana rekreasi yang tersedia. Kondisi demikian memudahkan pertikaian rumah tangga yang tak kunjung berakhir, yang lama-kelamaan berakibat terjadinya ledakan amarah sehingga pelaku tidak segan-segan untuk menghabisi pasangannya. ${ }^{10-13}$

Hasil penelitian mendapatkan bahwa variabel jenis kelamin korban laki-laki lebih banyak dibandingkan perempuan. Temuan ini sejalan dengan Langelo et $\mathrm{al}^{3}$ berdasarkan data tahun 2018-2019 yang menunjukkan dari total 17 korban pembunuhan semuanya berjenis kelamin laki-laki. Bila dibandingkan dengan data di Inggris yaitu dari total 215 kasus kematian tidak wajar yang terjadi, terdapat kasus pembunuhan partner intim (intimate partner homicide) sebanyak $85 \%$ korban berjenis kelamin perempuan. ${ }^{10}$ Tren ini bisa dijelaskan dengan perbedaan budaya dan kondisi kejahatan antara Indonesia dan Inggris. Di Indonesia terutama di Kota Manado, jenis kelamin laki-laki lebih memiliki kecenderungan untuk terlibat tindakan kriminalitas dibandingkan perempuan. Faktor pendorongnya antara lain budaya dan pergaulan yang kurang baik. ${ }^{2,3}$ Oleh sebab itu lebih banyak kasus pembunuhan yang terjadi antara kelompok kelompok tertentu apalagi bila korban dan pelaku sudah mengonsumsi minuman beralkohol yang menyebabkan penurunan kesadaran; hal ini menjadi pemicu untuk terjadinya suatu kasus pembunuhan. ${ }^{2,3}$ Di Inggris sendiri, korban terbanyak berjenis kelamin perempuan karena kaum perempuan lebih rawan untuk menjadi korban diakibatkan ketergantungan terhadap pasangan apalagi dalam permasalahan ekonomi sehingga walaupun hubungan dengan pasangannya ini sering diwarnai dengan kekerasan baik fisik maupun verbal namun sang korban tidak berani untuk berbicara ataupun melaporkan karena takut akan hukuman. Selain itu korban merasa khawatir dengan keadaan hidupnya apalagi bila korban tidak mempunyai pekerjaan dan sangatlah sukar untuk mendapatkan sumber penghasilan ataupun pekerjaan tetap dan stabil selama masa pandemi. ${ }^{10,12}$

Berdasarkan tanggal pemeriksaan didapatkan bahwa kasus terbanyak pada bulan Juli 2020-Oktober 2020, yaitu sebanyak 5 kasus $(71 \%)$, sedangkan pada bulan November 2020-Februari 2021 hanya terdapat 2 kasus (28\%). Yang menarik ialah tidak terdapat kasus pembunuhan pada bulan Maret 2020-Juni 2020. Hal ini dapat disebabkan karena terjadinya Pemberlakuan Pembatasan Kegiatan Masyarakat (PPKM) oleh pemerintah negara Indonesia dalam rangka untuk menekan angka kasus COVID-19.

Gambar 5A memperlihatkan bahwa pada bulan Maret 2020-Juni 2020 pandemi COVID-19 mulai mengalami kenaikan kasus mingguan sehingga pemerintah menerapkan PPKM. Seiring berjalannya PPKM seluruh masyarakat tinggal bersama keluarga sendiri atau bersama pasangan maupun keluarga pasangan mereka. Akibat hal tersebut serta didukung oleh ketakutan yang luar biasa akan tertular COVID-19 maka seluruh masyarakat Kota Manado mengikuti aturan pemerintah dan melaksanakan segala kegiatan dari rumah masing-masing. Hal ini dapat menjelaskan mengapa pada periode ini tidak terdapat kasus pembunuhan. Selain itu kemungkinan tidak seorangpun yang berani 
A.

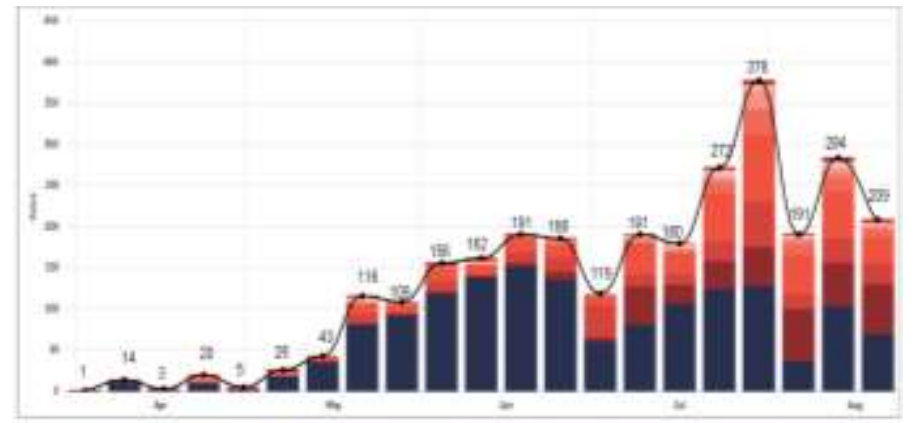

B.

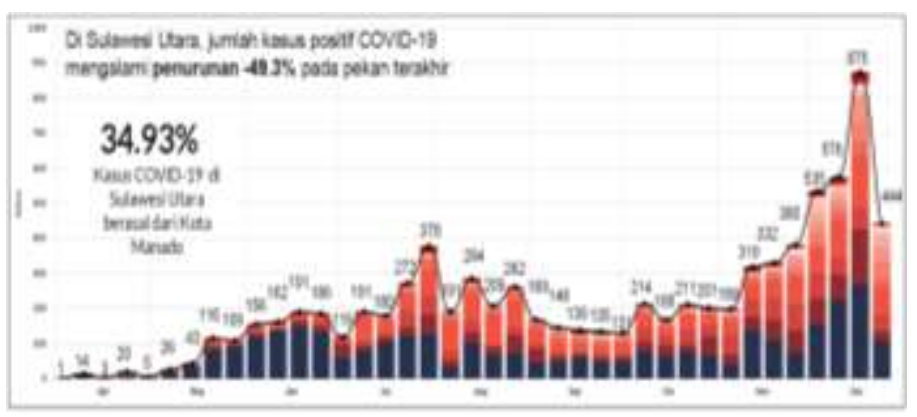

C.

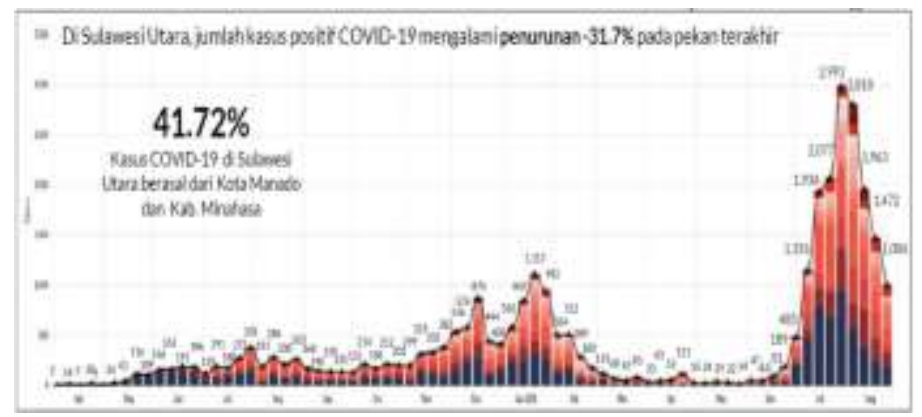

Gambar 5. Grafik analisis data kasus COVID-19 di Sulawesi Utara. A, per bulan Agustus 2020; B, per bulan Desember 2020; C, per bulan Agustus 2021

berbuat kejahatan karena takut akan risiko tertular COVID-19. ${ }^{14,15}$

Gambar 5B memperlihatkan mengenai kenaikan kasus pembunuhan pada bulan Juli 2020-Oktober 2020 yang jumlahnya cukup banyak yaitu 5 kasus (71\%). Kenaikan kasus yang besar terjadi pada pertengahan bulan Juli 2020 dan nilai kasus COVID-19 terus fluktuatif hingga bulan Oktober 2020. Walaupun sebenarnya selama bulan Oktober 2020 jumlah kenaikan kasus tidak begitu signifikan seperti pada bulan Juli 2020, namun angka kasus pembunuhan yang tinggi mungkin menunjukkan pola perilaku masyarakat yang masih suka berkeliaran walaupun sudah diberlakukan aturan pemerintah untuk tetap beraktivitas dari rumah saja. Selain itu, adanya beberapa perilaku kesehatan yang kurang baik seperti sering terlihat di jalanan banyak orang yang masih salah memakai masker ataupun tidak memakai masker sama sekali.

Gambar 5B dan 5C dapat membantu memberikan gambaran mengapa kasus pembunuhan pada bulan November 2020Februari 2021 tidak begitu banyak bila dibandingkan periode sebelumnya pada Juli 2020-Oktober 2020 yang hanya mencatatkan 2 kasus (29\%). Gambar 5B dan 5C memperlihatkan bahwa dari bulan November 2020 hingga bulan Januari 2021 terdapat tren peningkatan yang konstan dari angka kasus COVID-19 di Sulawesi Utara dan mengalami penurunan pada bulan Februari 2021. Kenaikan ini mungkin disebabkan oleh masyarakat banyak yang keluar untuk berbelanja keperluan maupun hadiah untuk liburan Natal dan Tahun Baru. Tidak jarang 
juga terlihat masyarakat yang turun ke kota berombongan sampai belasan orang di dalam satu mobil. Namun kasus pembunuhan relatif sedikit pada periode tersebut. Menurut asumsi penulis, hal ini dapat disebabkan karena pada saat liburan hampir semua orang berada dalam suasana hati yang gembira dan tidak memikirkan hal lain selain ingin bersenang-senang selama masa liburan. Pemikiran seperti ini bisa jadi ikut berkontribusi terhadap rendahnya kasus pembunuhan. Selain itu juga kebanyakan orang sudah tinggal bersama keluarga masing-masing sehingga kemungkinan terjadi saling salah paham menjadi kecil sebab keluarga pasti ingin bertukar salam setelah sekian lama tidak bertemu.

Hasil penelitian mendapatkan bahwa jenis kekerasan didominasi oleh kekerasan tajam. Jumlah kasus dengan kekerasan tajam sebanyak empat kasus (57\%) dan kekerasan tumpul sebanyak tiga kasus (43\%). Dengan penggunaan senjata, luka yang dihasilkan dapat berupa luka iris, luka sayat, luka tikam, maupun luka bacok. Luka-luka sejenis ini lebih mematikan dan lebih mungkin menyebabkan kematian pada pasien apabila tidak mendapatkan penanganan secara cepat dan tepat. Selain itu dikarenakan mudahnya akses untuk mendapatkan senjata tajam maka senjata tajam menjadi pilihan utama bagi banyak pelaku kejahatan. ${ }^{2,3}$

\section{SIMPULAN}

Angka kasus pembunuhan pada era pandemi COVID-19 periode Maret 2020Februari 2021 di RSUP Prof Dr. R. D. Kandou Manado mengalami penurunan sebesar $41 \%$ dibandingkan dengan saat sebelum pandemi. Kasus terbanyak didapatkan pada bulan Juli 2020, jenis kelamin laki-laki, dengan sebab kematian berupa kekerasan tajam.

\section{Konflik Kepentingan}

Penulis menyatakan tidak terdapat konflik kepentingan dalam studi ini.

\section{DAFTAR PUSTAKA}

1. Maramis MR, Kalangit A. Peran ilmu forensik dalam penyelesaian kasus kejahatan seksual dalam dunia maya (Internet). J Ilmu Huk. 2015;2(1):42-53.

2. Liempepas VF, Mallo JF, Mallo NTS. Kematian akibat pembunuhan di Kota Manado yang masuk Bagian Forensik RSUP Prof. Dr. R. D. Kandou Manado tahun 2014. e-CliniC. 2016;4(1):29-36. Doi:10.35790/ecl.4.1.2016.10836

3. Langelo AP, Kristanto EG, Mallo NTS. Profil pembunuhan di Kota Manado Tahun 2018-2019. e-CliniC. 2021;9(2):271-8. Doi:10.35790/ecl.v9i2.32848

4. Roux C, Weyermann C. Can forensic science learn from the COVID-19 crisis? Forensic Sci Int. 2020;316(January): 110503.

Doi:10.1016/j.forsciint.2020.110503

5. Djalante R, Lassa J, Setiamarga D, Sudjatma A, Indrawan M, Haryanto B, et al. Review and analysis of current responses to COVID-19 in Indonesia: Period of January to March 2020. Prog Disaster Sci. 2020;6(January):100091. Doi:10.1016/j.pdisas.2020.100091

6. Lopez E, Rosenfeld R. Crime, quarantine, and the U.S. coronavirus pandemic. Criminol Public Policy. 2021;20(3): 401-22. Doi:10.1111/1745-9133.12557

7. Barbot O. George Floyd and Our Collective Moral Injury. Am J Public Health. 2020;110(9):1253.

Doi:10.2105/AJPH.2020.305850

8. Sherman GT, Giorgi S, Steven O, Reynolds ME, Ungar LH. Correction for Eichstaedt et al., The emotional and mental health impact of the murder of George Floyd on the US population. Proc Natl Acad Sci. 2021;118(47): e2118233118. Doi:10.1073/pnas.2118233118

9. Gross N, Mann M. Is there a "Ferguson effect?" Google Searches, Concern about Police Violence, and Crime in U.S. Cities, 2014-2016. Socius Sociol Res a Dyn World. 2017;3:237802311770312. Doi:10.1177/2378023117703122

10. Bates L, Hoeger K, Stoneman M-J, Whitaker A. Vulnerability Knowledge and Practice Programme (VKPP): Domestic Homicides and Suspected Victim Suicides during the Covid-19 Pandemic. Published online 2021:87. Available from: https://assets.publishing.service. gov.uk/government/uploads/system/upl oads/attachment_data/file/1013128/Do 
150 Medical Scope Journal (MSJ), Volume 3, Nomor 2, Januari-Juni 2022, hlm. 143-150

mestic_homicides_and_suspected_victi m_suicides_during_the_Covid-

19_Pandemic_2020-2021.pdf

11. Ashby MPJ. Initial evidence on the relationship between the coronavirus pandemic and crime in the United States. Crime Sci. 2020;9(1):1-16. Doi:10.1186/s40163-020-00117-6

12. Langton S, Dixon A, Farrell G. Six months in: pandemic crime trends in England and Wales. Crime Sci. 2021;10(1):1-16. Doi:10.1186/s40163-021-00142-z
13. Ludwig J. Pandemic spread of violence: COVID-19 and criminal governance in Rio de Janeiro. Public Sph. 2021:29-34.

14. Byard RW. Geographic variability in homicide rates following the COVID-19 pandemic. Forensic Sci Med Pathol. 2021; 0123456789):19-21. Doi:10.1007/s12024-021-00370-4

15. Abrams DS. COVID and crime: An early empirical look. J Public Econ. 2021; 194(January):104344.

Doi:10.1016/j.jpubeco.2020.104344 